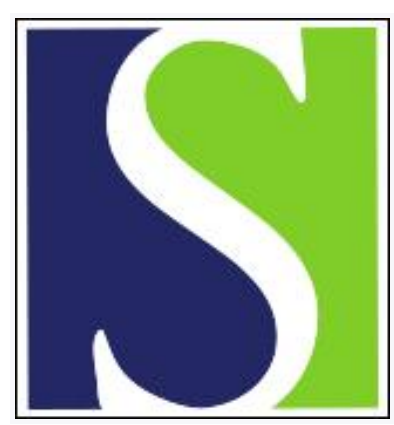

Scand J Work Environ Health 2003;29(4):251-260

https://doi.org/10.5271/sjweh.729

Issue date: Aug 2003

Adverse health effects from ambient air pollution in relation to residential wood combustion in modern society

by Boman $B C$, Forsberg $A B$, Järvholm BG

Affiliation: Inorganic Chemistry, Umeå University, SE-901 87 Umeå, Sweden. christoffer.boman@chem.umu.se

Key terms: adverse health effect; air pollution; ambient air pollution; asthma; biomass combustion; epidemiology; modern society; particulate matter; residential wood combustion; review; short-term exposure; wood smoke

This article in PubMed: www.ncbi.nlm.nih.gov/pubmed/12934718 


\title{
Adverse health effects from ambient air pollution in relation to residential wood combustion in modern society
}

\author{
by B Christoffer Boman, BSc, ${ }^{1}$ A Bertil Forsberg, PhD, ${ }^{2}$ Bengt G Järvholm, $M D^{2}$
}

\begin{abstract}
Boman BC, Forsberg AB, Järvholm BG. Adverse health effects from ambient air pollution in relation to residential wood combustion in modern society. Scand J Work Environ Health 2003;29(4):251-260.

This is a review of the adverse health effects of ambient air pollution in relation to residential wood combustion in modern society. From a literature search of PubMed, nine relevant studies were identified. All of them focused on the effects of short-term exposure such as asthma, respiratory symptoms, daily mortality, and lung function. Substantial quantitative information was only found for acute asthma in relation to particulate matter with an aerodynamic diameter of $<10 \mu \mathrm{m}$. In comparison with the present general estimations for ambient particulate matter and adverse health effects, the relative risks were even stronger in the studies in which residential wood combustion was considered a major source of particulate matter. Thus there seems to be no reason to assume that the effects of particulate matter in areas polluted by wood smoke are weaker than elsewhere.
\end{abstract}

Key terms air pollution, asthma, biomass combustion, epidemiology, particulate matter, review, short-term exposure, wood smoke.

The combustion of biomasses is the oldest and, overall, most widespread energy source used in a variety of applications for heat and power production, as well as for cooking. The everyday life for a majority of the people in the world is dependent on fuels like wood, animal dung, and crop residues, as well as coal $(1,2)$. Still, only a small fraction $(\sim 11 \%)$ of the total global energy consumption is based on biomass fuels or other combustible renewable material and waste (3). In the industrialized world and colder climates, biomasses are mainly used to produce heat either in large and medium-size district heating systems or in residential wood log boilers, stoves, and fireplaces. An increasing interest in sustainable energy production has awakened globally, and the potential for an increased use of biomass fuels, such as carbon dioxide $\left(\mathrm{CO}_{2}\right)$ neutral energy, is significant (4).
However, combustion processes in general are major anthropogenic sources of many of the classical air pollutants, for example, carbon monoxide (CO), nitrogen oxides $\left(\mathrm{NO}_{\mathrm{x}}\right)$, sulfur dioxide $\left(\mathrm{SO}_{2}\right)$, and particulate matter (PM), which have traditionally been associated with different negative environmental health effects. The contribution of $\mathrm{SO}_{2}$ and $\mathrm{NO}_{\mathrm{x}}$ from the combustion of wood and other biomass fuels has today subordinated the emissions from fossil fuels used in traffic, industry, and energy production $(5,6)$. However, residential wood combustion is often considered a major source of ambient local air pollutants, especially for hydrocarbons and PM. Besides the major combustion products $\mathrm{CO}_{2}$ and water, wood smoke mainly consists of a complex mixture of inorganic gases [eg, $\mathrm{CO}$, nitrogen oxide (NO), and $\mathrm{SO}_{2}$ ], volatile organic hydrocarbons (VOC), polycyclic aromatic compounds (PAC) and PM. PM can be

1 Inorganic Chemistry, Umeå University, Umeå, Sweden.

2 Public Health and Clinical Medicine, Umeå University, Umeå, Sweden.

Reprint requests to: B Christoffer Boman, Inorganic Chemistry, Umeå University, SE-901 87 Umeå, Sweden. [E-mail: christoffer.boman@chem.umu.se] 
fractionated as inorganic ash material, soot, and condensed organic material. CO, soot, and organic compounds are products of incomplete combustion, and the amounts are strongly dependent on combustion efficiency. The most currently used residential wood appliances are relatively old, and, compared with modern wood and pellet technology, the combustion conditions are poorly optimized. This situation often results in considerable emissions of products of incomplete combustion.

In the United States, it has been estimated that up to $90 \%$ of the ambient wintertime $\mathrm{PM}_{2.5}$ (mass of particles with an aerodynamic diameter of $\leq 2.5 \mu \mathrm{m}$ ) in Seattle, Washington (7), and correspondingly 20-30\% in Denver, Colorado (8), derive from residential wood combustion. With the use of ${ }^{14}$ carbon $\left({ }^{14} \mathrm{C}\right)$ as a tracer for contemporary carbonaceous material, the contribution from residential wood combustion to atmospheric carbon bound to $\mathrm{PM}_{2.5}$ in the winter has been estimated to be $44 \%$ in Portland, Oregon (9), close to $30 \%$ in the urban Los Angeles, California, area (10), and 65\% in Elverum, Norway $\left(\mathrm{PM}_{3.0}\right)$ (11). Source apportionment studies using organic compounds in California have also identified residential wood combustion as one of the major contributors to primary fine $\left(\mathrm{PM}_{2.0}\right)$ particulate matter (12). In Boise, Idaho, it has been estimated that most $(52-89 \%)$ of the extractable organic material in ambient PM derive from residential wood combustion (13, $14)$. In all but two $(12,14)$ of the aforementioned studies, ${ }^{14} \mathrm{C}$ methods were used to identify the impact of residential wood combustion on ambient air quality. Other methods, like chemical mass balance (7) and source apportionment with organic compounds (12), or combinations of different methods (8) have also been used. However, many of the studies are relatively old, and there are large uncertainties associated with the estimations. Current estimations are based on relatively few measurement campaigns, and uncertainties occur about the actual emissions from different kinds of appliances during practical use. It is also of interest whether the contribution from residential wood combustion to some ambient pollution parameter used so far (eg, particle bound carbon or $\mathrm{PM}_{10}$ ) also reflects the relevant impact on human health.

Today, the focus concerning emissions from residential wood combustion and its implications for air quality and human health is mainly on PM. Although some work has been done, a relatively limited number of studies with careful characterization of the PM from residential wood combustion has been performed. PM from residential wood combustion seems to be dominated by submicron $(<1 \mu \mathrm{m})$ particles with average mass diameters between 0.1 and $0.6 \mu \mathrm{m}$ (15-18). The chemical composition or fractionation of the particles (inorganic ash, soot, and organic material) varies with the combustion conditions for different fuels in different apparatus. One early study distinguished between hot rapid burning and cool-air-starved burning in a residential stove fired by fir and oak (19). The hot burning resulted in a monomodal particle distribution with approximately $95 \%$ of the particles being $<0.6 \mu \mathrm{m}$, consisting of $20-60 \%$ carbon (primarily elemental carbon) but also some potassium, chlorine, and sulfur. Cool burning, on the other hand, resulted in a bimodal distribution with 55-60\% as carbon (mostly organic carbon) and negligible amounts of trace elements $(<1 \%)$. Later studies have also determined that the main fraction of the PM from residential wood combustion is organic and elemental carbon in different proportions $(7,15,20)$. In large and medium-size biomass combustion devices, the combustion conditions are more optimized and stable, with considerably decreased amounts of soot and hydrocarbons. The particle emissions are therefore dominated by the inorganic (ash) constituents potassium, sodium, sulfur, and chlorine in the submicron fraction, while a minor but varying fraction of coarse $(>1 \mu \mathrm{m})$ fly ash particles containing refractory elements like calcium, silicon, magnesium, and aluminum can also be present (21-23). If trace elements like cadmium, lead, and zinc are present in the fuel, they can be volatilized during combustion in all kinds of appliances and can be found as condensed species of submicron PM (24).

Since the emissions from biomass combustion (eg, residential wood combustion) include a complex mixture of the aforementioned pollution components, it can be assumed that exposure to wood smoke is potentially harmful to human health. There has been a relatively extensive amount of work done concerning the adverse biological effects and toxicity of both individual gaseous combustion by-products, for example, $\mathrm{CO}(25), \mathrm{NO}_{\mathrm{x}}$ $(26,27)$ and $\mathrm{SO}_{2}(28)$, as well as particulate air pollution (29-31). However, fewer studies have dealt with the effects of exposure to wood smoke as a complex mixture in different environments. Exposure to wood smoke can occur both outdoors in the ambient air and indoors as a result of direct release from cooking and heating devices, leakage from boilers and stoves, or the infiltration of outdoor air pollution. In addition, some occupational groups (eg, firefighters) can be exposed to different kinds of biomass smoke. When the potential associations between wood smoke exposure and adverse health effects are in question, it is important to consider the fact that the pollution concentrations often vary significantly between indoor and outdoor environments and also between different geographic areas. In table 1, we have therefore roughly summarized the typical pollution concentrations of some major air-quality parameters in different environments. In general, indoor exposure is associated with higher concentrations of many pollution components than 
Table 1. Pollution concentrations of some major air-quality parameters in different environments. (TSP = total suspended particles, $\mathrm{PM}_{10}=$ particulate matter with an aerodynamic diameter of $10 \mu \mathrm{m}, \mathrm{SO}_{2}=$ sulfur dioxide, $\mathrm{NO}_{2}=$ nitrogen dioxide)

\begin{tabular}{|c|c|c|c|c|c|c|}
\hline & \multirow{2}{*}{$\begin{array}{l}\text { TSP } \\
\text { (annual mean } \\
\mu \mathrm{g} / \mathrm{m}^{3} \text { ) }\end{array}$} & \multicolumn{2}{|l|}{$\mathrm{PM}_{10}$} & \multirow{2}{*}{$\begin{array}{l}\mathrm{SO}_{2} \\
\text { (annual mean } \\
\mu \mathrm{g} / \mathrm{m}^{3} \text { ) }\end{array}$} & \multicolumn{2}{|l|}{$\mathrm{NO}_{2}$} \\
\hline & & $\begin{array}{l}\text { Annual mean } \\
\left(\mu \mathrm{g} / \mathrm{m}^{3}\right)\end{array}$ & $\begin{array}{l}\text { Daily mean } \\
\left(\mu \mathrm{g} / \mathrm{m}^{3}\right)\end{array}$ & & $\begin{array}{l}\text { Annual mean } \\
\left(\mu \mathrm{g} / \mathrm{m}^{3}\right)\end{array}$ & $\begin{array}{l}\text { 1-hour maximum } \\
\left(\mu \mathrm{g} / \mathrm{m}^{3}\right)\end{array}$ \\
\hline \multicolumn{7}{|l|}{ Ambient urban air } \\
\hline Developed countries & $20-50^{\text {a }}$ & $20-50^{a}$ & $4-132^{b}$ & $20-40^{a}$ & $20-90^{\text {a, c }}$ & $75-1000^{a, c}$ \\
\hline Developing countries & $\leq 300^{a}$ & $>100^{a}$ & $\begin{array}{l}. \\
\text { (peak conctration } \\
\leq 2000 \text { ) }\end{array}$ & $\leq 300^{a}$ & $20-90$ a, c & $75-1000$ a, c \\
\hline \multicolumn{7}{|l|}{ Indoor air } \\
\hline Developed countries & .. & .. & .. & .. & $\geq 200^{a, d}$ & $\geq 2000$ a d \\
\hline Developing countries & $\leq 2000-5000$ a e & \multicolumn{2}{|c|}{$\begin{array}{l}\text { (peak concentration } \\
<30000 \text { ) }\end{array}$} & .. & $\geq 200^{a, d}$ & $\geq 2000$ a d \\
\hline
\end{tabular}

a $\mathrm{WHO}(54)$.

${ }^{\mathrm{b}}$ Atkinson et al (55).

c Traffic-related pollution in cities.

${ }^{d}$ In homes with gas heating and poor ventilation.

e In homes using biomass fuels for cooking or heating.

${ }^{f}$ Bruce et al (33).

outdoor exposure is, although the relation between outdoor and indoor concentrations can vary significantly.

Exposure to indoor air pollution from residential wood combustion is a major health concern, especially in developing countries. The combustion of coal and biomasses in the form of wood, dung, and crop residues as domestic energy sources causes unhealthy indoor air pollution in poorly ventilated houses. According to a great number of epidemiologic studies, it has been estimated that indoor air pollution in developing countries is responsible for nearly two million excess deaths annually caused by, for example, chronic obstructive pulmonary disease, tuberculosis, acute respiratory disease, and cancer $(32,33)$.

In addition to epidemiologic studies, also animal toxicology and controlled human studies contribute to the knowledge of the toxicity of different compounds or pollution mixtures. However, no controlled human exposure studies have been reported that deal with wood smoke. On the other hand, more animal toxicology studies have been performed with wood smoke. In a recent review, Zelikoff and her co-workers (34) have summarized the toxicology of wood smoke. Although the work to some extent covers the issue from a human perspective, the focus and most extensively discussed area is animal studies of wood smoke exposure. It has been concluded that the inhalation of combustion products from wood can probably have a significant impact on pulmonary homeostasis and the exacerbation of ongoing disease processes. From a limited number of epidemiologic studies concerning either indoor wood smoke exposure in rural areas or indoor wood smoke exposure of children living in homes heated with wood-burning devices, they concluded that children are more susceptible to wood smoke exposure than adults. The review by Zelikoff and her co-workers finally stressed the uncertainties regarding both the associations between longterm wood smoke exposure and adverse health effects, as well as the wood smoke component(s) that may be responsible for the observed effects.

In an earlier review on the emissions and noncancer respiratory effects of wood smoke by Larson \& Koenig (6), more attention was given to epidemiologic studies, both from indoor and outdoor ambient exposure. A total of ten epidemiologic studies were reviewed, of which five concerned ambient and indoor exposure. Of the five ambient exposure studies, three dealt with children and two with both children and adults. Coherence was found between the data, especially for the children, showing associations between wood smoke and adverse respiratory effects.

In light of the ongoing ambitions to increase the utilization of biomass-based energy, not at least in many industrialized parts of the world, together with the increasing concern about air pollution and health, it is important to study carefully the influences on air quality and human health in association with the current and future use of such energy systems. Although a considerable amount of work concerning wood combustion and its implications for air quality and human health has been performed, many questions still remain. One such urgent question is how residential wood combustion in modern society contributes to ambient concentrations of different air pollution parameters and how such pollution influences human health.

The objective with this study was to review the scientific literature concerning adverse health effects from ambient air pollution in relation to residential wood combustion in modern society and, if possible, to extract quantifications for the associations. 
Table 2. Summary of the epidemiologic studies (included in this review) on cardiopulmonary effects from exposure to ambient wood smoke. $\left(\mathrm{CO}=\right.$ carbon monoxide, $\mathrm{COH}=$ coefficient of haze, $\mathrm{fV}_{1}=$ forced expiratory volume in 1 second, $\mathrm{FVC}=$ forced vital capacity, IQR= interquartile range, $\mathrm{NO}_{2}=$ nitrogen dioxide, $\mathrm{O}_{3}=$ ozone, $\mathrm{COPD}=$ chronic obstructive pulmonary disease, $\mathrm{OR}=$ odds ratio, $\mathrm{RV} \mathrm{V}_{1} \mathrm{PC}$, conc $=$ methacholine provocative concentration required to produce a $20 \%$ decrease in $€ \mathrm{~V}_{1}, \mathrm{PE}=$ peak expiratory flow, $\mathrm{PER}=$ peak expiratory flow rate, $\mathrm{PM}_{1}=$ particulate matter with an aerodynamic diameter of $<1 \mu \mathrm{m}, \mathrm{PM}_{10}=$ particulate matter with an aerodynamic diameter of $\leq 10 \mu \mathrm{m}, \mathrm{PM}_{2.5}=$ particulate matter with an aerodynamic diameter of $\leq 2.5 \mu \mathrm{m}, \mathrm{RR}=$ relative risk, $\mathrm{SO}_{2}=$ sulfur dioxide)

\begin{tabular}{|c|c|c|c|c|c|c|}
\hline Study & Dependent variables & Design and study size & Location and period & Exposure assessment & $\begin{array}{l}\text { Confounding } \\
\text { control }\end{array}$ & Results \\
\hline $\begin{array}{l}\text { Hales et al, } \\
2000^{a}(38)\end{array}$ & Daily mortality & $\begin{array}{l}\text { Population study; } \\
\text { mean mortality (all } \\
\text { causes and ages) = } \\
7.2 \text { deaths/day }\end{array}$ & $\begin{array}{l}\text { Christchurch, New } \\
\text { Zealand; June 1988- } \\
\text { December } 1993\end{array}$ & $\begin{array}{l}\text { One monitoring site for } \\
\mathrm{SO}_{2}, \mathrm{NO}_{x}, \mathrm{CO}_{\text {and }} \mathrm{PM}_{10} \\
24-\text { hour } \mathrm{PM}_{10}=0-187 \\
\mu \mathrm{g} / \mathrm{m}^{3}, \text { mean }= \\
28 \mu \mathrm{g} / \mathrm{m}^{3}\end{array}$ & $\begin{array}{l}\text { Temperature, } \\
\text { season, time } \\
\text { trend, day of } \\
\text { week, holidays }\end{array}$ & $\begin{array}{l}10 \mu \mathrm{g} / \mathrm{m}^{3} \mathrm{PM}_{10} \text { (lag1), } \\
\mathrm{RR} 1.01 \text { (all causes), } \\
\text { RR } 1.04 \text { (respiratory } \\
\text { causes) }\end{array}$ \\
\hline $\begin{array}{l}\text { Yu et al, } \\
2000^{a}(39)\end{array}$ & $\begin{array}{l}\text { Asthma symptoms } \\
\text { as PER, use of } \\
\text { medication, degree } \\
\text { of night awakening } \\
\text { due to asthma \& a } \\
\text { symptom rating }\end{array}$ & $\begin{array}{l}\text { Panel study with daily } \\
\text { diaries; } 133 \text { children } \\
\text { (5-13 years of age); } \\
\text { average } 58 \text { (range } \\
\text { 28-112) days }\end{array}$ & $\begin{array}{l}\text { Seattle (WA), United } \\
\text { States; November } \\
\text { 1993-August } 1995\end{array}$ & $\begin{array}{l}\text { Six, three \& one mon- } \\
\text { itoring sites for } \mathrm{OO}(6) \text {, } \\
\mathrm{PM}_{10} \text { or } \mathrm{PM}_{1}(3) \& \\
\mathrm{SO}_{2}(1)\end{array}$ & $\begin{array}{l}\text { Day of week, } \\
\text { season, temp- } \\
\text { erature, age, race, } \\
\text { gender, baseline } \\
\text { height, } \mathrm{FV}_{1} \\
\mathrm{PC}_{20} \text { conc }\end{array}$ & $\begin{array}{l}\mathrm{RR}(\mathrm{OR}) \text { (for at least } \\
\text { one asthma symp- } \\
\text { tom) }(\operatorname{lag} 1)=1.30 \\
\text { per } 1 \mathrm{ppm} \mathrm{CO}, 1.17 \\
\text { per } 10 \mu \mathrm{g} / \mathrm{m}^{3} \mathrm{PM}_{1} \& \\
1.11 \text { per } 10 \mu \mathrm{g} / \mathrm{m}^{3} \mathrm{PM}_{10}\end{array}$ \\
\hline $\begin{array}{l}\text { Sheppard et } \\
\text { al, 1999a (40) }\end{array}$ & $\begin{array}{l}\text { Daily hospital admis- } \\
\text { sions for asthma }\end{array}$ & $\begin{array}{l}\text { Population study; per- } \\
\text { sons aged <65 years; } \\
23 \text { hospitals, mean } 2.7 \\
\text { admissions/day }\end{array}$ & $\begin{array}{l}\text { Seattle (WA), United } \\
\text { States; 1987-1994 }\end{array}$ & $\begin{array}{l}\text { Up to three monitoring } \\
\text { sites for } \mathrm{PM}_{10} \text { \& light } \\
\text { scattering, two sites for } \\
\mathrm{PM}_{2,5} \text {, four sites for } \mathrm{CO} \text {, } \\
\text { one site for } \mathrm{SO}_{2} \text { \& one } \\
\text { for } \mathrm{O}_{3} ; 24-\text { hour mean } \\
\mathrm{PM}_{10} 31.5 \mu \mathrm{g} / \mathrm{m}^{3} \text { \& } \\
\mathrm{PM}_{2,5} 16.7 \mu \mathrm{g} / \mathrm{m}^{3}\end{array}$ & $\begin{array}{l}\text { Temperature, } \\
\text { time trend \& } \\
\text { day of week }\end{array}$ & $\begin{array}{l}\text { IQR PM }{ }_{10}\left(19 \mu \mathrm{g} / \mathrm{m}^{3}\right) \\
(\operatorname{lag} 1), \mathrm{RR} 1.05 ; \mathrm{IQR} \\
\mathrm{PM}_{2.5}\left(12 \mu \mathrm{g} / \mathrm{m}^{3}\right)(\operatorname{lag} 1) \text {, } \\
\mathrm{RR} 1.04 ; \mathrm{IQR} \mathrm{CO} \\
(0.9 \mathrm{ppm})(\operatorname{lag} 3), \mathrm{RR} \\
\text { 1.06; IQR O }(20 \mathrm{ppb}) \\
\text { (lag 2), RR 1.06; PM } \\
\text { \& } \bigcirc \text { found to be } \\
\text { jointly associated with } \\
\text { asthma admissions }\end{array}$ \\
\hline
\end{tabular}

Norris et al, Daily hospital admis- Population study; per- Seattle (WA), United Three monitoring sites Temperature, dew IQR PM I0 $_{10}\left(12\right.$ $\mu$ g/m ${ }^{3}$ ) $1999^{\circ}$ (41) sions for asthma sons aged <18 years; States; September 6 hospitals, mean 1.8 admissions/day 1995-December 1996 for $\mathrm{PM}_{10}$ \& light scatpoint temperature, (daily average) RR tering (estimated $\mathrm{PM}_{2.5}$ ), time trend, day of 1.14 ; IQR PM $\mathrm{PM}_{2.5}(9.5$ four sites for $\mathrm{CO} \& \quad$ week, $\mathrm{NO}_{2} \& \mathrm{SO}_{2} ; \quad \mathrm{mg} / \mathrm{m}^{3}$ ) (daily average) two sites for $\mathrm{NO}_{2} \& \quad$ COassumed to $\quad$ RR 1.15; IQR CO $\mathrm{CO}$, 24-hour $\mathrm{PM}_{10} 8-70$ be a surrogate $(0.6 \mathrm{ppm})$ (daily $\mu \mathrm{g} / \mathrm{m}^{3}$, mean $22 \mu \mathrm{g} / \mathrm{m}^{3}$ for stagnant con- average) RR 1.10; no ditions and not impact of $\mathrm{NO}_{2} \& \mathrm{SO}_{2}$ included together on PM estimates with $\mathrm{PM}_{10}$

Vedal et al, $\quad$ PE \& respiratory 1998 (35) symptoms

Lipsett et al, Daily asthma emer1997 (36) gency room visits

Harré et al, 1997 a (42)

Respiratory symptoms \& PER in subjects with OOPD
Panel study with daily diaries; 40 subjects aged over 55 years

Panel study with daily Port Alberni, British diary; asthmatic and Columbia, Canada; nonasthmatic children 900501-920313 (ex(6-13 years); 206 chil- cept July \& August dren up to 492 days 1991) within 18 months

Population study; 3 hos- Santa Clara County pitals during 368 days, (CA), United States; mean 7.6 visits/day winter seasons (November-January) 1988 \& 1989-1991 \& 1992

Christchurch, New Zealand; 3 months during the winter, 1994 e monitoring site for $\mathrm{PM}_{10} ; 24$-hour $\mathrm{PM}_{10}$ 0-159 $\mathrm{mg} / \mathrm{m}^{3}$, mean $22 \mu \mathrm{g} / \mathrm{m}^{3}$
Temperature, humidity, precipita tion, time trend, day of week \& month
For asthmatics an increase of $10 \mu \mathrm{g} / \mathrm{m}^{3}$ in $\mathrm{PM}_{10}$ associated with reduction of $\mathrm{PEF}$ by $0.55 \mathrm{I} / \mathrm{min}$ and increased odds of cough with $\mathrm{RR}(\mathrm{OR})$

1.08; associations similar below $40 \mu \mathrm{g} / \mathrm{m}^{3}$

One monitoring site for Temperature, hu- $60 \mathrm{mg} / \mathrm{m}^{3} \mathrm{PM}_{10}$ (lag 2) $\mathrm{PM}_{10}, \mathrm{CoH}, \mathrm{NO}_{2}$ and $\mathrm{O}_{3}$; midity, precipita- $\mathrm{RR} 1.43$ (low temperamore than $50 \%$ of the tion, time trend, ture), RR 1.11 (mean $\mathrm{PM}_{10}$ values predicted day of week (also temperature); $\mathrm{NO}_{2}$ were $(r=0.81) ; 24$-hour $\mathrm{PM}_{10}$ 9-165 $\mu \mathrm{g} / \mathrm{m}^{3}$, mean $61 \mu \mathrm{g} / \mathrm{m}^{3}$ interactions) significant only without $\mathrm{PM}_{10}$ in model

One monitoring site for Previous day out- IQR PM $10\left(35 \mu \mathrm{g} / \mathrm{m}^{3}\right)$ $\mathrm{PM}_{10}, \mathrm{NO}_{2}, \mathrm{SO}_{2}$ \& $\mathrm{O}$ come, temperature, RR 1.38 for chest wind speed, time symptoms and no eftrend, other pollu- fect on PE; IQR NO tants

$\left(10 \mu \mathrm{g} / \mathrm{m}^{3}\right) \mathrm{RR} 1.42$ for increased inhaler use \& RR 2.81 for increased nebulizer use

Population study; 2995 Seattle (WA), United visits at 8 hospitals States; 1 September during 13 months, mean 7.1 visits/day
1989-30 Septembe 1990
One monitoring site for $\mathrm{PM}_{10}$, light scattering,

$\mathrm{SO}_{2} \& \mathrm{O}_{3} ; 24$-hour $\mathrm{PM}_{10} 6-103 \mu \mathrm{g} / \mathrm{m}^{3}$, mean $30 \mu \mathrm{g} / \mathrm{m}^{3}$
Temperature, sea- Asthma attendance for September peak years associated with (and also other models) sons, day of week, persons under age 65
Schwartz et al, Daily asthma emer$1993^{a}$ (43) gency room visits years associated with $\mathrm{PM}_{10} ; 30 \mu \mathrm{g} / \mathrm{m}^{3} \mathrm{PM}_{10}$ $\mathrm{RR}=1.12$; light scattering showed compa rable associations 
Table 2. Continued.

Koenig et $\mathrm{al}, \quad \mathrm{EV}_{1}$ \& $\mathrm{FVC}$ $1993(37)$

\begin{tabular}{|c|c|c|c|c|}
\hline $\begin{array}{l}\text { Panel study, follow-up } \\
\text { with repeated spiromet- } \\
\text { ry; } 326 \text { children (first } \\
\text { year) and } 20 \text { children, } \\
\text { all asthmatics (second } \\
\text { year) in grade } 3 \text { to } 6\end{array}$ & $\begin{array}{l}\text { Seattle (WA), United } \\
\text { States; winter season } \\
\text { 1988-1989 \& 1989- } \\
1990\end{array}$ & $\begin{array}{l}\text { Two monitoring sites } \\
\text { for fine particulate with } \\
\text { light scattering (nephe- } \\
\text { lometer) and } \mathrm{PM}_{2.5} \text { (gra- } \\
\text { vimetric) }\end{array}$ & $\begin{array}{l}\text { Height, relative hu- } \\
\text { midity, temperature, } \\
\text { parental smoking, } \\
\text { - wood stove at } \\
\text { home, allergy or } \\
\text { asthma }\end{array}$ & $\begin{array}{l}\text { For asthmatic children } \\
\text { an increase of } 20 \\
\mu \mathrm{g} / \mathrm{m}^{3} \text { in } \mathrm{PM}_{2.5} \text { was } \\
\text { associated with a } \\
\text { reduction of } \mathrm{EV} \mathrm{V}_{1} \\
(-34 \mathrm{ml}) \text { \& } \mathrm{FVC}(-37 \mathrm{ml})\end{array}$ \\
\hline
\end{tabular}

${ }^{a}$ Not identified in the PubMed search but still filled criteria ii-v and thereby are relevant.

\section{Subjects and methods}

A literature search of PubMed was performed using a search profile combining MeSH terms ${ }^{3}$ with general keywords. PubMed provides access to bibliographic information, which is drawn primarily from MEDLINE, Pre-MEDLINE, HealthSTAR, and publisher-supplied citations.

The search profile used in PubMed was as follows: (air pollution [MeSH Terms] OR air pollutants [MeSH Terms]) AND human [MeSH Terms] AND (wood [all fields] OR biomass [all fields] OR biofuel* [all fields] OR bio fuel* [all fields] OR pellet* [all fields]).

Based on the literature, search references that fulfilled the following inclusion criteria were included for further analysis: (i) in PubMed (1965-2001) with the previously described search profile, (ii) an epidemiological study, (iii) concerning adverse health effects from ambient air pollution concentrations (not indoor or occupational exposure), (iv) from settings in which residential wood combustion was mentioned as an important air pollution source, (v) full scientific paper published in English (not review articles).

In addition, other scientifically published studies fulfilling criteria ii to $\mathrm{v}$, although not found in the literature search, were also taken into consideration. Such additional papers could be identified as (i) a reference in, (ii) a reference related to, or (iii) a study from the same area as a paper already included through the literature search.

\section{Results}

\section{General search results}

With the use of the search profile, altogether 614 references were initially identified in PubMed. The vast majority of them filled criterion i, ii, and $\mathrm{v}$, and several of them also filled criterion iii. However, criterion iv, which stated that the study should be from settings in which residential wood combustion was mentioned as an important air pollution source, showed high selectivity. Only three references (35-37) filled all five inclusion criteria. In addition, eight other relevant papers (38-45) were also identified. However, two of the eight were not considered for further analysis, one (44) because the air pollution monitoring parameter used (coefficient of haze) is an old method that is very difficult to relate to current PM monitoring methods and the other (45) because the study time period was relatively short (4 months) and the statistical analysis so inadequate that we considered it irrelevant. However, a significant number $(\mathrm{N}=29)$ of the total 614 studies initially identified concerned indoor air pollution and adverse health effects, of which 23 were epidemiologic studies involving respiratory symptoms and six involved cancer.

Overall, nine papers were included for further analysis, and they were either population studies $(\mathrm{N}=5)$ or panel studies ( $\mathrm{N}=4$ ). In table 2 (on pages 254-255), the included papers are briefly summarized according to design, content, and results.

\section{Long-term exposure}

We found no relevant long-term exposure studies with health outcomes like cardiopulmonary mortality, lung cancer, or chronic bronchitis.

\section{Short-term exposure}

The included studies focused on the effects of variations of short-term exposure, such as asthma, respiratory symptoms, daily mortality, and lung function. In table 3, the studied health outcomes presented in the included papers are summarized.

\section{Environments}

Only the following four different geographic areas have been studied; Seattle, Washington, and Santa Clara

MeSH (Medical Subject Headings) is the controlled vocabulary of biomedical terms used by the National Library of Medicine in the United States to describe the subject of each journal article. MeSH contains more than 19000 terms and is updated annually. Applying the MeSH vocabulary ensures that articles are uniformly indexed by subject whatever the author's words. 
Table 3. Summary of the addressed health effects and brief results from the reviewed papers. $(C O=$ carbon monoxide, $\mathrm{CoH}=\mathrm{coefficient}$ of haze, $\mathrm{PM}_{1}=$ particulate matter with an aerodynamic diameter $\leq 1 \mu \mathrm{m}, \mathrm{PM}_{10}=$ particulate matter with an aerodynamic diameter $\leq 10 \mu \mathrm{m}$, $\mathrm{PM}_{2.5}=$ particulate matter with an aerodynamic diameter $\leq 2.5 \mu \mathrm{m}, \mathrm{O}_{3}=$ ozone, $\mathrm{SO}_{2}=$ sulfur dioxide, $\mathrm{NO}_{2}=$ nitrogen dioxide, $\mathrm{NO}_{x}=$ nitrogen oxides, COPD = chronic obsructive pulmonary disease)

\begin{tabular}{|c|c|c|c|c|}
\hline Efect & Reference & Subjects' ages & Pollution indicators & Significant positive associations with \\
\hline Daily mortality & 38 & All ages & $\mathrm{PM}_{10}, \mathrm{SO}_{2}, \infty, \mathrm{NO}_{x}$ & $\mathrm{PM}_{10}$ \\
\hline Asthma symptoms & 39 & $5-13$ years & $\mathrm{PM}_{10}, \mathrm{PM}_{1}, \mathrm{SO}_{2}, \infty$ & $\mathrm{PM}_{10}, \mathrm{PM}_{1}, \infty$ \\
\hline \multirow[t]{2}{*}{ Asthma hospital admissions } & 40 & $<65$ years & $\mathrm{PM}_{10}, \mathrm{PM}_{2.5}, \infty, \mathrm{SO}_{2}, \mathrm{O}_{3}$ & $\mathrm{PM}_{10}, \mathrm{PM}_{2.5}, \infty, \mathrm{O}_{3}$ \\
\hline & 41 & $<18$ years & $\mathrm{PM}_{10}, \mathrm{PM}_{2.5}, \infty, \mathrm{NO}_{2}$ & $\mathrm{PM}_{10}, \mathrm{PM}_{2.5}, \infty$ \\
\hline \multirow[t]{2}{*}{ Asthma emergency room visits } & 36 & All ages & $\mathrm{PM}_{10}, \mathrm{NO}_{2}, \mathrm{O}_{3}, \mathrm{CoH}$ & $\mathrm{PM}_{10}$ \\
\hline & 43 & All ages & $\mathrm{PM}_{10}, \mathrm{SO}_{2}, \mathrm{O}_{3}$ & $\mathrm{PM}_{10}$ \\
\hline \multirow{2}{*}{$\begin{array}{l}\text { Peak expiratory flow and } \\
\text { respiratory symptoms }\end{array}$} & 35 & Children & $\mathrm{PM}_{10}$ & $\mathrm{PM}_{10}$ (asthmatics) \\
\hline & 42 & > 55 (COPD) & $\mathrm{PM}_{10}, \mathrm{SO}_{2}, \infty, \mathrm{NO}_{2}$ & $\mathrm{PM}_{10}, \mathrm{NO}_{2}$ \\
\hline $\begin{array}{l}\text { Forced expiratory volume in } 1 \\
\text { second and forced vital capacity }\end{array}$ & 37 & $\begin{array}{l}\text { Children } \\
\text { (grades } 3 \text { to } 6 \text { ) }\end{array}$ & Fine particulate, $\mathrm{PM}_{2.5}$ & $\mathrm{PM}_{2.5}$ (asthmatics) \\
\hline
\end{tabular}

County, California in the United States, Port Alberni, British Columbia, in Canada, and Christchurch in New Zealand. Five of the included studies were conducted in the Seattle metropolitan area and two in Christchurch.

\section{Exposure parameters}

Different exposure assessment parameters were used in the included papers. The most common indicators were $\mathrm{PM}_{10}$ (8 studies), $\mathrm{SO}_{2}$ (5 studies), $\mathrm{CO}$ (5 studies), and $\mathrm{NO}_{\mathrm{x}} / \mathrm{NO}_{2}$ (4 studies). $\mathrm{PM}_{2.5}, \mathrm{PM}_{1}$, and ozone $\left(\mathrm{O}_{3}\right)$ were only occasionally used.

\section{Associations}

All of the studies reported positive significant associations between variations in air pollution level(s) and adverse health outcome(s). PM was the parameter that showed the most frequent and most obvious associations with the addressed health effects. In all the studies using $\mathrm{PM}_{10}, \mathrm{PM}_{2.5}$, or $\mathrm{PM}_{1}$ as an indicator, significant positive associations were found. $\mathrm{PM}_{10}$ was the most commonly used indicator for ambient particulate matter $(8$ studies). Overall, the relative risks (RR) between an increase in ambient $\mathrm{PM}_{10}$ with $10 \mu \mathrm{g} / \mathrm{m}^{3}$ and different health outcomes varied between 1.018 and 1.117. CO showed significant positive associations with the addressed effects in three out of the four studies (not reference 35) including $\mathrm{CO}$ in the analysis. All three of these studies were from the Seattle area and showed associations between increases in $\mathrm{CO}$ and the worsening of asthma (RR 1.30, 1.07, and 1.17 per 1 ppm CO). Only in one (35) of the four studies was an association with $\mathrm{NO}_{2}$ established, while associations with $\mathrm{SO}_{2}$ or $\mathrm{O}_{3}$ were not found in any study.

\section{Discussion}

Only the effects of short-term exposure to air pollution in relation to residential wood combustion has been studied, with different asthma-related outcomes as the most common measured effect. However, this is a general pattern in air pollution epidemiology. One reason for the lack of data (long-term studies) is the difficulties in conducting epidemiologic studies on such longterm effects, when many potential confounding parameters (eg, smoking, occupational exposure, nutrition) become difficult and expensive to measure and adjust for. Associations with some measured health outcomes were reported for particulate matter and, to some extent, $\mathrm{CO}$. Of these two air pollutants, wood smoke has probably a large relative effect on local air quality and also long-term mean concentrations during heating seasons. During the last few decades, many epidemiologic studies have been performed concerning ambient PM and different health effects. Particulate matter in ambient air is today generally considered an important indication that air pollution causes adverse health effects. Epidemiologic evidence exists that links increases in PM mass concentrations with cardiopulmonary disease and mortality, especially in association with short-term exposure (31, 46-48), but also for long-term exposure (49). Potential health risks have also been associated with air pollutants other than PM, in both epidemiologic and clinical or experimental studies (50). Elevated levels of urban air pollutants are also associated with increased cancer risks $(49,51-53)$.

We attempted to extract some kind of quantification of the associations, but found that there was substantial information only for acute asthma in relation to $\mathrm{PM}_{10}$ exposure. However, we compared the results from the studies included in this review with the estimations for 
the association between PM and health effects in the general environment. For these comparisons we used a guideline from the World Health Organization (WHO) (54), a "state of the art" review (31), and a recent European study (55). WHO has established health-based air quality guidelines (54) in which particulate matter is regarded as a key air pollutant and estimations are made of the relative increases in various health parameters as a function of PM concentrations. A recent review has also summarized the associations between PM and adverse health effects (31). In addition, an extensive European study (55), also concerning respiratory hospital admissions, has recently been reported. Therefore, in figure 1, we have compared the results from the five wood smoke studies with associations between increases in ambient $\mathrm{PM}_{10}$ and asthma symptoms, hospital admissions, and emergency room visits, together with one study with associations for cough.

For health impact assessments it is important to know if associations between an indicator of PM and some health effect (eg, acute asthma) are the same regardless of the contribution from different sources (eg, residential wood combustion), that is, if we should assume the same dose-response function. Due to differences in the statistical analyses (inclusion of covariates) and presentation of the results (selection of lag times) it is difficult to compare the results from different studies. However, figure 1 gives some indications of the relations. All the included studies showed significant positive associations and, in comparison with the estimations of WHO and other "state of the art" estimations concerning ambient PM and health, the effects (RR) are even stronger in the few studies in which residential wood combustion is considered a major PM source. Thus there seems to be no reason to assume that the health effects associated with PM in areas polluted with wood smoke are weaker than elsewhere. However, there are not enough data to allow for a comparison of different PM indicators (eg, if $\mathrm{PM}_{10}$ is better than $\mathrm{PM}_{2.5}$, etc).

We found only these few studies in which residential wood combustion was identified as a (or the) major source of ambient air pollution. One reason can be that wood smoke emissions are often the dominating air pollutant only in rural areas and small towns and that there are difficulties associated with studying sparsely populated areas using epidemiologic methods. However, of the four studied areas, only Port Alberni can be considered a small rural town, while the other three are large cities. Nevertheless, residential wood combustion has, in these urban areas, been considered a major source of ambient air pollution. In Seattle, three of the five studies $(37,40,41)$ refer to the same reference $(56)$, in which source apportionment estimations indicate that,

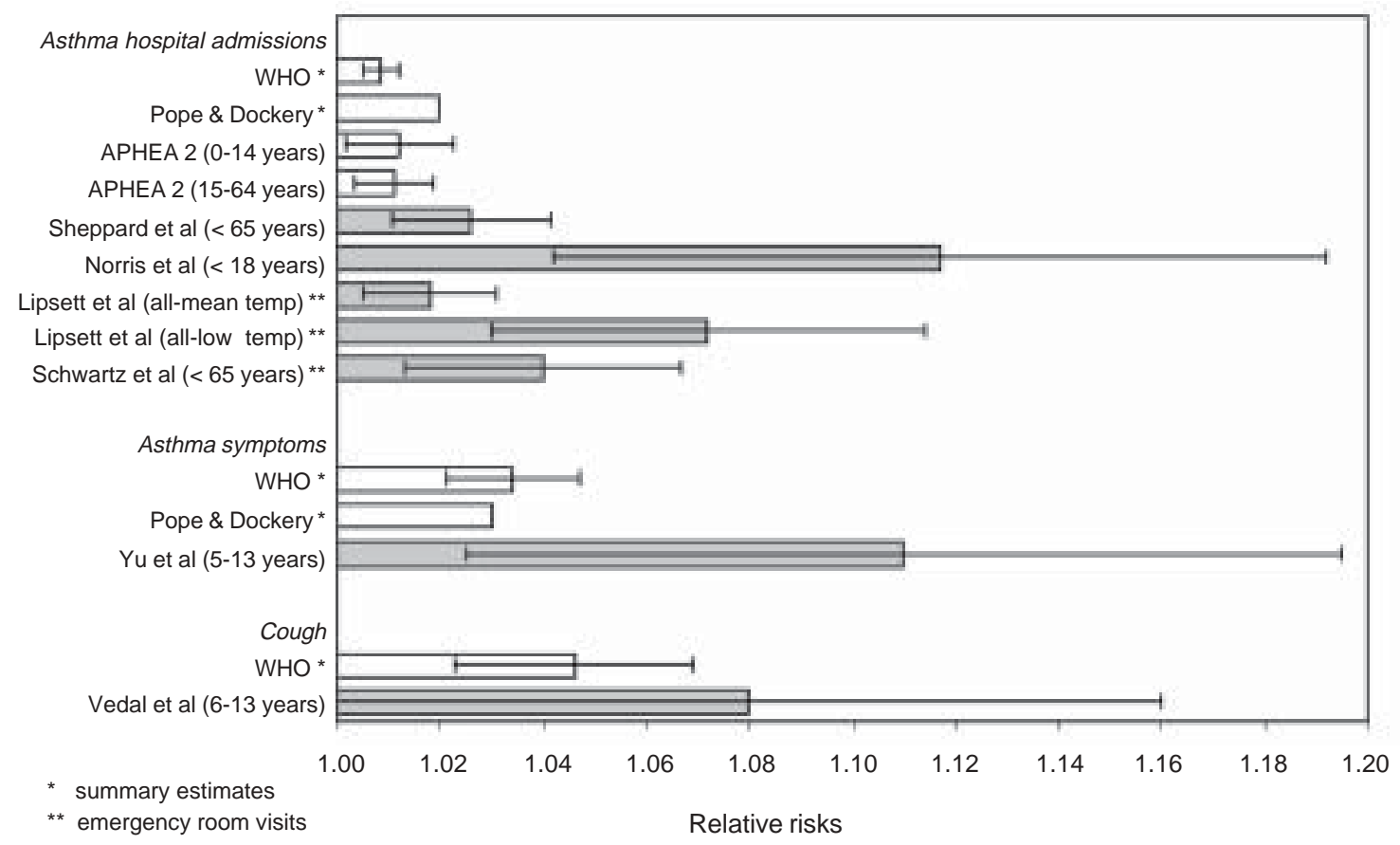

Figure 1. Relative risks for different morbidity outcomes in association with a $10 \mu \mathrm{g} / \mathrm{m}^{3}$ increase in $\mathrm{PM}_{10}$ (particulate matter with an aerodynamic diameter of $<10 \mu \mathrm{g}$ ) with $95 \%$ confidence intervals as error bars. The studies in which wood smoke was considered a major air pollution source are shown by closed columns, and the comparison estimates are represented by open columns (temp = temperature, APHEA2 = European study by Atkinson et al (55), $\mathrm{WHO}=$ World Health Organization). 
during the heating season (October-March), $>80 \%$ of the ambient $\mathrm{PM}_{2.5}$ derives from wood burning devices. In the fourth study (43), the authors stated, without any reference, that "the primary source of fine particulate matter in residential neighborhoods during the winter heating season is from wood burning". In the fifth Seattle study (39) the origin of the air pollution was not mentioned at all. In the Santa Clara County study (36), a reference is given (57) in which the source apportionment estimate indicates that an average of $45 \%$ of wintertime $\mathrm{PM}_{10}$ derives from residential wood combustion. In the Port Alberni study (35), it is only stated that "main sources of ambient particulate pollution are the pulp mill boilers and residential wood burning", without any references being given. The first Christchurch study (38) states, without a reference, that "domestic fires (both coal and wood) and motor vehicles are primary sources of air pollution". In the later Christchurch study (42), however, the authors refer to a local emission inventor study (58) and, according to a personal communication, the authors make the assumption that most of the ambient $\mathrm{PM}_{10}$ in Christchurch derives from residential wood combustion (personal communication with Professor Tord Kjellström, New Zealand Environmental and Occupational Health Research Center, and Department of Community Health, The University of Auckland, New Zealand). Accordingly, only in studies from two areas (Seattle and Santa Clara County), does there seem to exist some published material that confirms that residential wood combustion is a major source of ambient PM in the areas. In the other two areas (Port Alberni and Christchurch) the assumptions are not that strong, and, therefore, the interpretation of the results from these studies is more uncertain. However, the reviewed studies included in the comparison in figure 1 are in fact from Seattle $(39-41,43)$ and Santa Clara (36), where residential wood combustion has been identified as a major source of atmospheric PM concentrations. Nevertheless, the small number of studies, as well as the uncertainties about the actual contribution from residential wood combustion to ambient concentrations of PM, limits the conclusions about the adverse health effects associated with exposure to air pollution related to residential wood combustion at this time.

In most of the studied areas, residential wood combustion was expected to be an important source of ambient PM mainly during the winter season. Yet, several studies used observation periods of years, including months in which wood smoke pollution was not a major factor. However, only two $(35,40)$ of the reviewed studies reported seasonal effect estimations, and, in one study (43), the issue was, to some extent, addressed in the discussion. Vedal et al (35) found the effect estimates for the autumn-winter period (September-March) essentially identical with those for the spring period (March-June), although with different standard errors. Sheppard et al (40) have also made season-specific estimates (for an increase in the interquartile range), which were negative (not significant) for summer, but were higher for spring and fall than for the winter season. The separate winter estimate was close to significance. The authors further suggested that their results indicate a persistent effect of pollution from automobiles on health. In the study of Schwartz et al (43), the effect estimations were based on the whole study period (1 year), and they suggest that the high PM concentrations in association with asthma visits during the winter reflect, in large part, the toxicity of wood smoke. However, they also comment on the fact that these associations continue even at relatively low PM concentrations, and, therefore, wood smoke is probably not the only contributing factor.

As emphasized in this paper, as well as in previous work, the general focus today regarding air pollution and health is, to a large extent, on PM. Much attention in the ongoing work within this field is therefore given to the emission characteristics and possible links between, for example, particle properties and different adverse health effects. However, the amount of data concerning detailed physical and chemical characterizations of the particle emissions from different combustion technologies is still limited. In addition, any specific particle property or component responsible for the toxicologic effects have not yet been identified, but the importance of particle properties other than mass concentration, like chemical composition, particle size, and number concentration, has been emphasized $(59,60)$.

In this study we have focused on residential wood combustion in modern society. A limited number of relevant studies has been performed in which residential wood combustion has been identified as a major source of air pollution. Significant information was only found for a relationship between acute asthma and $\mathrm{PM}_{10}$ exposure, and the associations between PM exposure in areas polluted by wood smoke seem at least not to be weaker than elsewhere. The results, although associated with significant uncertainties, indicate higher risk estimations (RR) for areas polluted by wood smoke, especially for children. This finding also agrees with today's general consensus that exposure to wood smoke, even in ambient concentrations, is associated with adverse respiratory effects. Globally, the topic of residential biomass combustion is also of major concern in developing countries, both from a global warming and human health perspective. To facilitate a significant increased future use of biomasses as an energy source, it is therefore important to evaluate the total impact on the environment and human health from the use of different fuels and combustion techniques. 


\section{Acknowledgments}

Ninni Broms Dahlgren at the National Institute for Working Life in Umeå is acknowledged for her help during the literature search.

The financial support of the Center for Environmental Research in Umeå (CMF) and the Swedish Energy Agency (STEM) is gratefully acknowledged.

\section{References}

1. Reddy AKN, Williams RH, Johansson TB, editors. Energy after Rio: prospects and challenges. New York (NY): United Nations Publications; 1996.

2. de Koning HW, Smith KR, Last JM. Biomass fuel combustion and health. Bull World Health Organ 1985;63(1):11-26.

3. International Energy Agency. Key world statistics. IEA Publications, 2002. Available from: URL: http://www.iea.org/statist/keyworld2002/key2002/keystats.htm

4. Fischer G, Schrattenholzer L. Global bioenergy potentials through 2050. Biomass Bioenerg 2001;20(3):151-9.

5. US Environmental Protection Agency (USEPA). National air pollutant emission trends report, 1990-1998. Research Triangle Park (NC): USEPA; 2000. EPA 454/R-00-002.

6. European Environment Agency (EEA). CORINAIR 1994 Inventory. Copenhagen: EEA; 1998. Topic Report 8/1997.

7. Larson TV, Koenig JQ. Wood smoke: emissions and noncancer respiratory effects. Annu Rev Public Health 1994;15:13356.

8. Muhlbaier Dasch J. Particulate and gaseous emissions from wood-burning fireplaces. Environ Sci Technol 1982;16(10): 639-45.

9. Cooper JA, Currie LA, Klouda GA. Assessment of contemporary carbon combustion source contributions to urban air particulate levels using carbon-14 measurements. Environ Sci Technol 1981;15(9):1045-50.

10. Hildemann LM, Klinedinst DB, Klouda GA, Currie LA, Cass GR. Sources of urban contemporary carbon aerosols. Environ Sci Technol 1994;28(9):1565-76.

11. Ramdahl T. Retene-A molecular marker of wood combustion in ambient air. Nature 1983;306(8):580-2.

12. Schauer JJ, Rogge WF, Hildemann LM, Mazurek MA, Cass GR, Simoneit BRT. Source apportionment of airborne particulate matter using organic compounds as tracers. Atmos Environ 1996;30(22):3837-55.

13. Klouda GA, Barraclough D, Currie LA, Zweidinger RB, Lewis CW, Stevens RK. Source apportionment of wintertime organic aerosols in Boise, ID, by chemical and isotopic $\left({ }^{14} \mathrm{C}\right)$ methods. In: Proceedings of the 84th annual meeting of the Air and Waste Management Association; 1991 June 16-21; Vancouver (BC): vol 15A (Nr. 91-131.2). Pittsburgh (PA): Air and Waste Management Association; 1991. p 1-15.

14. Lewis CW, Stevens RK, Zweidinger RB, Claxton LD, Barraclough D, Klouda GA. Source apportionment of mutagenic activity of fine particle organics in Boise, Idaho. In: Proceedings of the 84th annual meeting of the Air and Waste Management Association; 1991 June 16-21; Vancouver (BC): vol 15A (Nr. 91-131.2). Pittsburgh (PA): Air and Waste Management Association; 1991. p 1-12.

15. Kleeman MJ, Schauer JJ, Cass GR. Size and composition distribution of fine particulate matter emitted from wood burning, meat charbroiling and cigarettes. Environ Sci Technol 1999;33:3516-23.

16. Purvis CR, McCrillis RC. Fine particulate matter (PM) and organic speciation of fireplace emissions. Environ Sci Technol 2000;34:1653-8.

17. Hueglin C, Gaegauf C, Kûnzler S, Burtscher H. Characterization of wood combustion particles: morphology, mobility and photoelectric activity. Environ Sci Technol 1997;31:3439-47.

18. Wieser U, Gaegauf CK. Nanoparticle Emissions of wood combustion processes. In: Kyritsu S, Beenackers AACM, Helm P, Grassi A, Chiaramonti D, editors. Proceedings of the 1 st world conference and exhibition biomass for energy and industry; 2000 June 5-9; Sevilla, Spain. London: James \& James Ltd; 2001. p 805-8.

19. Rau JA. Composition and size distribution of residential wood smoke particles. Aerosol Sci Technol 1989;10:181-92.

20. Schauer JJ, Kleeman MJ, Cass GR, Simoneit BRT. Measurements of emissions from air pollution sources, 3: C1-C29 organic compounds from fireplace combustion of wood. Environ Sci Technol 2001;35:1716-28.

21. Chriestensen KA. The formation of submicron particles from the combustion of straw [dissertation]. Lyngby (Denmark): Technical University of Denmark; 1995.

22. Valmari T, Lind T, Kauppinen EI, Sfiris G, Nilsson K, Maenhaut W. Field study on ash behavior during circulating fluidized-bed combustion of biomass, 2: ash deposition and alkali vapor condensation. Energy Fuels 1999;13(2):390-5.

23. Brunner T, Dahl J, Obernberger I, Pölt P. Chemical and structural analyses of aerosols and fly-ash particles from fixedbed biomass combustion plants by electron microscopy. In: Kyritsu S, Beenackers AACM, Helm P, Grassi A, Chiaramonti $\mathrm{D}$, editors. Proceedings of the 1 st world conference and exhibition biomass for energy and industry; 2000 June 5-9; Sevilla, Spain. London: James \& James Ltd; 2001. p 1991-4.

24. Nordin A, Backman R. Heavy metal behavior during combustion and gasification of biomass fuels - comparison between chemical equilibrium and experimental results. In: Obernberger I, editor. Ashes and particulate emissions from biomass combustion-formation, characterization, evaluation, treatment. Graz: dbv-Verlag; 1998. p 119-34.

25. Maynard RL, Waller R. Carbon monoxide. In: Holgate ST, Samet JM, Koren HS, Maynard R, editors. Air pollution and health. London: Academic Press; 1999. p 749-96.

26. Hazucha MJ. Controlled exposure to ozone, nitrogen oxides and acids. In: Holgate ST, Samet JM, Koren HS, Maynard R, editors. Air pollution and health. London: Academic Press; 1999. p 511-29.

27. Ackermann-Liebrich U, Rapp R. Epidemiological effects of oxides of nitrogen, especially $\mathrm{NO}_{2}$. In: Holgate ST, Samet JM, Koren HS, Maynard R, editors. Air pollution and health. London: Academic Press; 1999. p 559-84.

28. Schlesinger RB. Toxicology of sulfur oxides. In: Holgate ST, Samet JM, Koren HS, Maynard R, editors. Air pollution and health. London: Academic Press; 1999. p 585-602.

29. Ghio AJ, Samet JM. Metals and air pollution particles. In: Holgate ST, Samet JM, Koren HS, Maynard R, editors. Air pollution and health. London: Academic Press; 1999. p 63551.

30. MacNee W, Donaldson K. Particulate air pollution: injurious and protective mechanisms in the lungs. In: Holgate ST, Samet JM, Koren HS, Maynard R, editors. Air pollution and health. London: Academic Press; 1999. p 653-72.

31. Pope CA III, Dockery DW. Epidemiology of particle effects. 
In: Holgate ST, Samet JM, Koren HS, Maynard R, editors. Air pollution and health. London: Academic Press; 1999. p 673705 .

32. Smith KR, Samet JM, Romieu I, Bruce N. Indoor air pollution in developing countries and acute lower respiratory infections in children. Thorax 2000;55:518-32.

33. Bruce N, Perez-Padilla R, Albalak R. Indoor air pollution in developing countries: a major environmental and public health challenge. Bull World Health Organ 2000;78(9):1078-92.

34. Zelikoff JT, Chen LC, Cohen MD, Schlesinger RB. The toxicology of inhaled woodsmoke. J Toxicol Environ Health B Crit Rev 2002;5:269-82.

35. Vedal S, Petkau J, White R, Blair J. Acute effects of ambient inhalable particles in asthmatic and nonasthmatic children. Am J Respir Crit Care Med 1998;157:1034-43

36. Lipsett M, Hurley S, Ostro B. Air pollution and emergency room visits for asthma in Santa Clara county, California. Environ Health Perspect 1997;105:216-22

37. Koenig JQ, Larson TV, Hanley QS, Rebolledo V, Dumler K, Checkoway $\mathrm{H}$, et al. Pulmonary function changes in children associated with fine particulate matter. Environ Res 1993; 63:26-38.

38. Hales S, Salmond C, Town GI, Kjellstrom T, Woodward A. Daily mortality in relation to weather and air pollution in Christchurch, New Zealand. Aust NZ J Public Health 2000; 24(1):89-91.

39. Yu O, Sheppard L, Lumley T, Koenig JQ, Shapiro GG. Effects of ambient air pollution on symptoms of asthma in Seattle-area children enrolled in the CAMP study. Environ Health Perspect 2000;108(12):1209-14.

40. Sheppard L, Levy D, Norris G, Larson TV, Koenig JQ. Effects of ambient pollution on nonelderly asthma hospital admissions in Seattle, Washington, 1987-1994. Epidemiology 1999;10:23-30.

41. Norris G, Young Pong SN, Koenig JQ, Larson TV, Sheppard L, Stout JW. An association between fine particles and asthma emergency department visits for children in Seattle. Environ Health Perspect 1999;107:489-93.

42. Harré ES, Price PD, Ayrey RB, Toop LJ, Martin IR, Town GI. Respiratory effects of air pollution in chronic obstructive pulmonary disease - a three month prospective study. Thorax 1997;52(12):1040-4.

43. Schwartz J, Slater D, Larson TV, Pierson WE, Koenig JQ. Particulate air pollution and hospital emergency room visits for asthma in Seattle. Am Rev Respir Dis 1993;147:826-31.

44. Fairley D. The relationship of daily mortality to suspended particulates in Santa Clara county, 1980-1986. Environ Health Perspect 1990;89:159-68.

45. Dawson KP, Allan J, Fergusson DM. Asthma, air pollution and climate: a Christchurch study. N Z Med J 1983;96:165-7.
46. Dockery DW, Pope CA, Xiping X, Spengler JD, Ware JH, Fay ME, et al. An association between air pollution and mortality in six U.S. cities. N Engl J Med 1993;329(24):1753-9.

47. Samet JM, Dominici F, Curriero FC, Coursac I, Zeger SL. Fine particulate air pollution and mortality in 20 U.S. cities, 1987-1994. N Engl J Med 2000;343(24):1742-9.

48. Pope CA Ø. Epidemiological basis for particulate air pollution health standards [review]. Aerosol Sci Technol 2000;32:4-14.

49. Pope CA III, Burnett RT, Thun MJ, Calle EE, Krewski D, Ito $\mathrm{K}$, et al. Lung cancer, cardiopulmonary mortality and longterm exposure to fine particulate air pollution. JAMA 2002;287(9):1132-41.

50. Holgate ST, Samet JM, Koren HS, Maynard R, editors. Air pollution and health. London: Academic Press; 1999.

51. Katsouyanni K, Pershagen G. Ambient air pollution exposure and cancer. Cancer Causes Control 1997;8:284-91.

52. Törnqvist M, Ehrenberg L. On cancer risk estimation of urban air pollution. Environ Health Perspect 1994;102 Suppl 4:17381.

53. Cohen AJ, Pope CA III. Lung cancer and air pollution. Environ Health Perspect 1995;103 Suppl 8:219-24.

54. World Health Organization (WHO). Guidelines for air quality. Geneva: WHO; 2000.

55. Atkinson RW, Anderson HR, Sunyer J, Ayres J, Baccini M, Vonk JM, et al. Acute effects of particulate air pollution on respiratory admissions - results from APHEA 2 project. Am J Respir Crit Care Med 2001;164:1860-6.

56. Larson TV, Yuen P, Maykut N. Weekly composite sampling of $\mathrm{PM}_{2.5}$ for total mass and trace elements analysis. In: Chow JC, Ono DM, editors. Proceedings of the Air and Waste Management Association Specialty Conference on $\mathrm{PM}_{10}$ Standards and Nontraditional Particulate Source Controls. 1992; Pittsburgh (PA), USA. Air and Waste Management Association; 1992. p 39-50.

57. Chow JC, Fairley D, Watson JG, De Mandel R, Fujita EM, Lowenthal DH, et al. Source apportionment of wintertime $\mathrm{PM}_{10}$ at San Jose, California. J Environ Eng - ASCE 1995;121: 378-87.

58. Canterbury Regional Council. Christchurch inventory of total emissions. Christchurch (NZ): Canterbury Regional Council; 1997.

59. Harrison RM, Yin J. Particulate matter in the atmosphere: which particle properties are important for its effects on health? Sci Total Environ 2000;249:85-101.

60. Lighty JS, Veranth JM, Sarofim AF. Combustion aerosols: factors governing their size and composition and implications to human health. J Air Waste Manage Assoc 2000;50(9):1565618.

Received for publication: 30 September 2002 